University of Nebraska - Lincoln

DigitalCommons@University of Nebraska - Lincoln

2012

Development of a Urea Bioprobe Based on Platinized BoronDoped Diamond Electrodes

\author{
Eduardo Nicolau \\ University of Puerto Rico \\ Jose J. Fonseca \\ University of Puerto Rico \\ Carlos R. Cabrera \\ University of Puerto Rico, carlos.cabrera2@upr.edu
}

Follow this and additional works at: https://digitalcommons.unl.edu/nasapub

Nicolau, Eduardo; Fonseca, Jose J.; and Cabrera, Carlos R., "Development of a Urea Bioprobe Based on Platinized Boron- Doped Diamond Electrodes" (2012). NASA Publications. 120.

https://digitalcommons.unl.edu/nasapub/120

This Article is brought to you for free and open access by the National Aeronautics and Space Administration at DigitalCommons@University of Nebraska - Lincoln. It has been accepted for inclusion in NASA Publications by an authorized administrator of DigitalCommons@University of Nebraska - Lincoln. 


\title{
Development of a Urea Bioprobe Based on Platinized Boron- Doped Diamond Electrodes
}

\author{
Eduardo Nicolau, José J. Fonseca, Carlos R. Cabrera* \\ Department of Chemistry and NASA-URC Center for Advanced Nanoscale Materials, University of Puerto Rico, Rio Piedras \\ Campus, PO Box 23346, San Juan, Puerto Rico, USA 00931-3346 \\ *e-mail: carlos.cabrera2@upr.edu
}

Received: August 22, 2012

Accepted: August 22, 2012

\begin{abstract}
Urea $\left(\mathrm{CH}_{6} \mathrm{ON}_{2}\right)$ is one of the main human nitrogen-based metabolic wastes. The concentration of urea in blood lies between $2.5-7 \mathrm{mM}$ for healthy individuals, and is commonly used as an indicator for several diseases that may alter this value. Spectrophotometric methods are employed for the determination of blood urea concentration during clinical assays. Although these methods are sensitive, they make use of toxic reagents and complex reaction schemes. Therefore, in this research we present the bioelectrochemical determination of urea by the use of the protein urease (E.C.3.1.1.5) along with a nano-platinized boron-doped diamond electrode. This approach has been proven to be efficient and sensitive providing a platform with detection limits of $1.79 \mathrm{mM}(S / N=3)$. The linear range resulted from $1 \mathrm{mM}$ to $25 \mathrm{mM}$ for the determination of urea, and response time of five minutes.
\end{abstract}

Keywords: Urea detection, Urease, Boron-doped diamond, Bioprobe

DOI: 10.1002/elan.201200459

\section{Introduction}

The human body produces a variety of biological wastes as a result of its numerous metabolic pathways. Protein metabolism is among the most common processes performed by the human body and in general, the majority of proteins are metabolized in the liver, where urea $\left(\mathrm{CH}_{6} \mathrm{ON}_{2}\right)$ is produced as one of the main nitrogen-based wastes. The normal levels of urea in blood lie between 2.5-7 mM [1,2] for healthy individuals, and is commonly used as an indicator for several diseases. Low urea levels are mainly related to liver diseases or malfunctioning whereas high levels of urea are mainly associated to renal and coronary diseases [3]. Therefore, the monitoring of urea levels is directly related to kidney function. When chronic kidney malfunctioning occurs in patients, dialysis treatment is necessary and urea concentration should remain approximately in a range of $3-16 \mathrm{mM}$ after such treatment $[1,4]$.

Indeed, spectrophotometric techniques are mostly employed for the determination of urea levels. These techniques involve the degradation of urea via the enzyme urease (E.C. 3.5.1.5) to produce ammonia via hydrolysis [5]. The released ammonia from the enzymatic reaction should undergo several reaction steps in order to produce spectrophotometrically active species. The Nessler reaction (Equation 1) [6,7] and the Berthelot reaction (Equation 2) [8] are among the most accepted methods for sensitive and accurate urea determination.

$$
\mathrm{NH}_{3}+2 \mathrm{~K}_{2}\left[\mathrm{HgI}_{4}\right]+3 \mathrm{OH}^{-} \rightarrow \mathrm{OHg}_{2}\left(\mathrm{NH}_{2}\right) \mathrm{I}+7 \mathrm{I}^{-+} 2 \mathrm{H}_{2} \mathrm{O}
$$

$$
\begin{aligned}
& \mathrm{NH}_{3}+\mathrm{OCl}^{-}+2 \mathrm{OH}^{-}+2 \mathrm{Phenolate} \rightarrow \\
& \text { Indophenolate }+3 \mathrm{H}_{2} \mathrm{O}+\mathrm{HCl}\left(\text { with }\left[\mathrm{Fe}(\mathrm{CN})_{5} \mathrm{ONO}\right]^{4-}\right)
\end{aligned}
$$

However these methods are far from providing fast and point-of-care testing since the methods are complicated and require highly trained professionals. Also, some of the compounds used in these reactions are quite toxic.

Therefore, strategies to provide sensitive and fast measuring while accomplishing point-of-care testing are being proposed from which amperometric biosensors shed a bright future. The most common urea amperometric biosensor is based on the interface of the enzyme urease and a selective electrode. The electrode can be selective to ammonium ion $\left(\mathrm{NH}_{4}^{+}\right)$[1], ammonia $[9,10]$, or to hydronium ion $\left(\mathrm{H}_{3} \mathrm{O}^{+}\right)$[11-13] depending on the working $\mathrm{pH}$ of the system since the amount of ammonia produced and its equilibrium with its conjugate acid will cause changes in the $\mathrm{pH}$. These systems are designed by entrapping the enzyme in a polymer (e.g. polyvinyl alcohol or polyacrilamide) while casting the selective sensor or by microencapsulation of the enzyme [1,10-14]. Therefore, urea has to diffuse through the polymer to reach the enzyme, in order for hydrolysis to occur, and then the product must diffuse to travel through the polymer until the selective membrane to permeate through it. After 
that, the analyte is detected and an analytical amperometric signal is measured. Generally, these systems have adequate working ranges to measure urea levels, ranging from $0.03-1 \mathrm{mM}$ to $30-1000 \mathrm{mM}[2,10,11,13]$. However, a major disadvantage of these biosensors consists in that the detection is completely dependent on the diffusion of the species through the polymer. Also, another disadvantage is that the selective membranes are not fully selective, allowing similar species to the analyte permeate through them causing discrepancies in the measurements, which could provide a false positive result.

For these reasons, in this work we propose a urea bioelectrochemical probe consisting on a boron-doped diamond electrode with platinum nanoparticles deposited at its surface and the enzyme urease free in buffer solution. In this system, urea is hydrolyzed by urease in solution, where the diffusion barrier of urea to urease is expected to be considerably lower than through a polymer, what should improve the sensitivity. Then the ammonia is oxidized at the platinized boron-doped diamond electrode (Pt-BDD), creating an electrochemical signal, as follows:

$2 \mathrm{NH}_{3}+\mathrm{OH}^{-} \rightarrow \mathrm{N}_{2}+6 \mathrm{H}_{2} \mathrm{O}+6 \mathrm{e}^{-}$

Therefore, the proposed bioelectrochemical probe should help to improve sensitivity and selectivity, in the measurements of urea levels, due to the high urease enzyme selectivity towards urea and the high sensitivity of the platinum nanoparticles to electroactive compounds, such as ammonia. Other advantage of this construction is that the boron-doped diamond electrodes have been proven to be highly conductive and resistant to nonspecific adsorption. These characteristics are known to minimize any background effects [15].

\section{Experimental}

\subsection{Materials and Apparatus}

Urea (ACS reagent, 99.0-100.5\%), urease (E.C.3.5.1.5, from Canavalia ensiformis (Jack bean) Type VII; initial activity of 400000-800000 units/g solid), potassium phosphate monobasic $\left(\mathrm{KH}_{2} \mathrm{PO}_{4}\right)$, potassium phosphate dibasic $\left(\mathrm{K}_{2} \mathrm{HPO}_{4}\right)$, sulfuric acid $\left(\mathrm{H}_{2} \mathrm{SO}_{4}\right.$, TraceSELECT Ultra, $\geq 95 \%(\mathrm{~T})$ ), nitric acid $\left(\mathrm{HNO}_{3}\right)$, hydrochloric acid $(\mathrm{HCl})$, potassium chloride $(\mathrm{KCl})$, potassium hydroxide $(\mathrm{KOH})$, potassium ferricyanide $\left(\mathrm{K}_{3} \mathrm{Fe}(\mathrm{CN})_{6}\right)$, potassium ferrocyanide $\left(\mathrm{K}_{4} \mathrm{Fe}(\mathrm{CN})_{6}\right)$, ammonium sulfate $\left(\left(\mathrm{NH}_{4}\right)_{2} \mathrm{SO}_{4}\right)$, phenol-nitroprusside, alkaline hypochlorite, creatinine (anhydrous) and potassium hexachloroplatinate IV $\left(\mathrm{K}_{2} \mathrm{PtCl}_{6}, 99.99+\%\right.$ trace metals basis) were all purchased from Sigma Aldrich (USA) and used without further purification. An HCP-803 potentiostat/galvanostat in low current mode from BioLogic USA, along with a common glass three-electrode cell system was used for all the electrochemical procedures. The boron-doped diamond (BDD) substrate (Element 6, 0.038-0.105 $\Omega, \quad$ [B]: $10^{20} \mathrm{~cm}^{-3}$ ) was used as the working electrode, $\mathrm{Ag} / \mathrm{AgCl}$
(0.197 vs. NHE) as the reference electrode and a platinum wire as the counter electrode. A UV-Vis spectrophotometer from Shimadzu Co. was also used along with a $1 \mathrm{~cm}$ path length quartz cuvette.

\subsection{Electrode Preparation and Characterization}

First, the boron-doped diamond electrodes were oxidized by sweeping the cell potential between $-1.0 \mathrm{~V}$ and $2.5 \mathrm{~V}$ vs. $\mathrm{Ag} / \mathrm{AgCl}$ in a $0.5 \mathrm{M} \mathrm{HNO}_{3}$ solution for 45 consecutive cycles at a scan rate of $100 \mathrm{mV} \mathrm{s}^{-1}$. Thereafter, the electrode was washed several times with deionized water (Barnstead 18.2 M $\Omega$ ) and dried under $\mathrm{N}_{2}$ for further use. Then, the reversibility capacity of the BDD electrode was measured using the cyclic voltammetry $(\mathrm{CV})$ technique. The potential was swept between $-0.1 \mathrm{~V}$ and $0.6 \mathrm{~V}$ vs. $\mathrm{Ag} / \mathrm{AgCl}$ in a $1 \mathrm{mM} \mathrm{K}{ }_{3} \mathrm{Fe}(\mathrm{CN})_{6} / 1 \mathrm{mM} \mathrm{K}_{4} \mathrm{Fe}(\mathrm{CN})_{6} / 0.1 \mathrm{M}$ $\mathrm{KCl}$ for a period of three cycles. This process was performed before and after the electrochemical oxidation. After the oxidation process, platinum was electrodeposited over the boron-doped diamond electrodes. Scans from $-0.2 \mathrm{~V}$ and $1.0 \mathrm{~V}$ vs. $\mathrm{Ag} / \mathrm{AgCl}$ in a $1 \mathrm{mM} \mathrm{K}_{2} \mathrm{PtCl}_{6} / 0.5 \mathrm{M}$ $\mathrm{H}_{2} \mathrm{SO}_{4}$ solution at scan rate of $300 \mathrm{mV} \mathrm{s}^{-1}$ was performed to achieve electrodeposition. Then, the platinized borondoped diamond (Pt-BDD) electrode was thoroughly washed with deionized water. Immediately after washing, a cyclic voltammetry was recorded by using a $0.5 \mathrm{M}$ sulfuric acid solution to account for the cleanliness and electrochemical active area of the platinum deposits. Scanning electron microscopy (SEM) images were obtained using a JEOL 5800LV Scanning Microscope with an electron beam of $20 \mathrm{kV}$.

\subsection{Ammonia Oxidation at Pt-BDD Electrodes (pH 8.3 and 7.4)}

The electrochemical oxidation of ammonia at $\mathrm{pH} 7.4$ and 8.3 was investigated with a $0.1 \mathrm{M}\left(\mathrm{NH}_{4}\right)_{2} \mathrm{SO}_{4}$. In brief, the linear polarization technique was employed from $-0.3 \mathrm{~V}$ to $0.7 \mathrm{~V}$ vs. $\mathrm{Ag} / \mathrm{AgCl}$ at $100 \mathrm{mV} / \mathrm{s}$.

\subsection{Urea Bioprobe Measurements}

In order to measure the analytical amount of ammonia molecules being produced via the hydrolysis of urea from the enzyme urease (E.C.3.5.1.5) a calibration curve was performed (data not shown). The Weatherburn method was used following a similar procedure as published elsewhere $[16,17]$. In this assay, $50 \mu \mathrm{L}$ of ammonia solution of different concentrations were mixed with $500 \mu \mathrm{L}$ of phenol-nitroprusside and then with $500 \mu \mathrm{L}$ of alkaline hypochlorite after vigorous shaking before each addition. These samples were incubated at $37^{\circ} \mathrm{C}$ for 30 minutes and then measured at a wavelength of $630 \mathrm{~nm}$ in a UVVis Spectrophotometer. After having the calibration curve for ammonia we proceed with the enzymatic assay. For the enzymatic assay a protein final concentration of $0.02 \mathrm{mg} / \mathrm{mL}$ was selected as a first approach. For all ex- 
periments a $100 \mathrm{mM}$ phosphate buffer solution of $\mathrm{pH} 7.0$ and 8.0 was used. To execute the urease assay $100 \mu \mathrm{L}$ of a $0.2 \mathrm{mg} / \mathrm{mL}$ urease solution was mixed with final urea concentrations of 10,50 , and $100 \mathrm{mM}$ with the vial completed to $1 \mathrm{~mL}$ with PBS. Aliquots of $50 \mu \mathrm{L}$ of this mixture were extracted over time and mixed with the phenolnitroprusside and sodium alkaline hypochlorite.

Therafter, to test the complete system, a $4 \mathrm{mg} / \mathrm{mL}$ stock solution of urease in $100 \mathrm{mM}$ PBS was prepared fresh the day of the experiment. Then, $1.25 \mathrm{~mL}$ of the enzyme stock solution and different amounts of urea solutions in stock were poured into the electrochemical cell, completing with $100 \mathrm{mM}$ PBS to a final volume of $5 \mathrm{~mL}$ in the cell. Therefore, the final concentration of urease in the cell was around $1 \mathrm{mg} / \mathrm{mL}$, while the urea concentration ranged from $1 \mathrm{mM}$ up to $100 \mathrm{mM}$. In order to measure only the faradic current (related to the transfer of electrons during an electrochemical chemical reaction) the differential pulse voltammetry (DPV) technique was employed. After letting the enzymatic reaction undergo for 5 minutes, a DPV was carried out from $-0.1 \mathrm{~V}$ to $0.7 \mathrm{~V}$ vs. $\mathrm{Ag} / \mathrm{AgCl}$ with a pulse height of $50 \mathrm{mV}$, pulse duration of $50 \mathrm{~ms}$, step high of $2 \mathrm{mV}$ and step duration of $400 \mathrm{~ms}$.

Finally, in order to determine the specificity of the system, creatinine was added as interference due to its similarity. The experiments consisted in two parts, first the creatinine was measured in the system without urea, and then both urea and creatinine were measured together in order to observe the effect of its presence. A stock solution of $100 \mathrm{mM}$ creatinine in $100 \mathrm{mM}$ PBS was prepared to measure $50 \mathrm{mM}$ creatinine in the presence of $0.5 \mathrm{mg} / \mathrm{mL}$ urease, $10 \mathrm{mM}$ urea and completing with $100 \mathrm{mM}$ PBS to a final volume of $5 \mathrm{~mL}$ in the cell. After letting the enzymatic reaction undergo for 5 minutes, a linear polarization was carried out from $-0.3 \mathrm{~V}$ to $0.7 \mathrm{~V}$ vs. $\mathrm{Ag} / \mathrm{AgCl}$.

\section{Results and Discussion}

\subsection{Electrode Characterization}

Prior to electrochemical deposition, the boron-doped diamond electrodes employed in this research were anodically oxidized in order to create a hydrophobic layer, which provides a more suitable environment for metal deposition. As shown in Figure 1, after anodic oxidation of BDD the electrode showed an increment in current of $25 \%$ and better reversibility $(0.51 \mathrm{~V}$ (non-oxidized) vs. $0.39 \mathrm{~V}$ (oxidized)) when tested with a redox couple of $\mathrm{Fe}(\mathrm{CN})_{6}^{3-/ 4-}$ in $0.1 \mathrm{M} \mathrm{KCl}$. Also, in this figure an SEM image is shown as an inset where it can be observed the difference in coloration of the oxidized part of the electrode (light circle). This data suggests that the electrode is highly conductive after oxidation and therefore is prepared for further platinum electrodeposition.

Afterwards, platinum was electrodeposited over the BDD previously oxidized by following procedures in Sec-

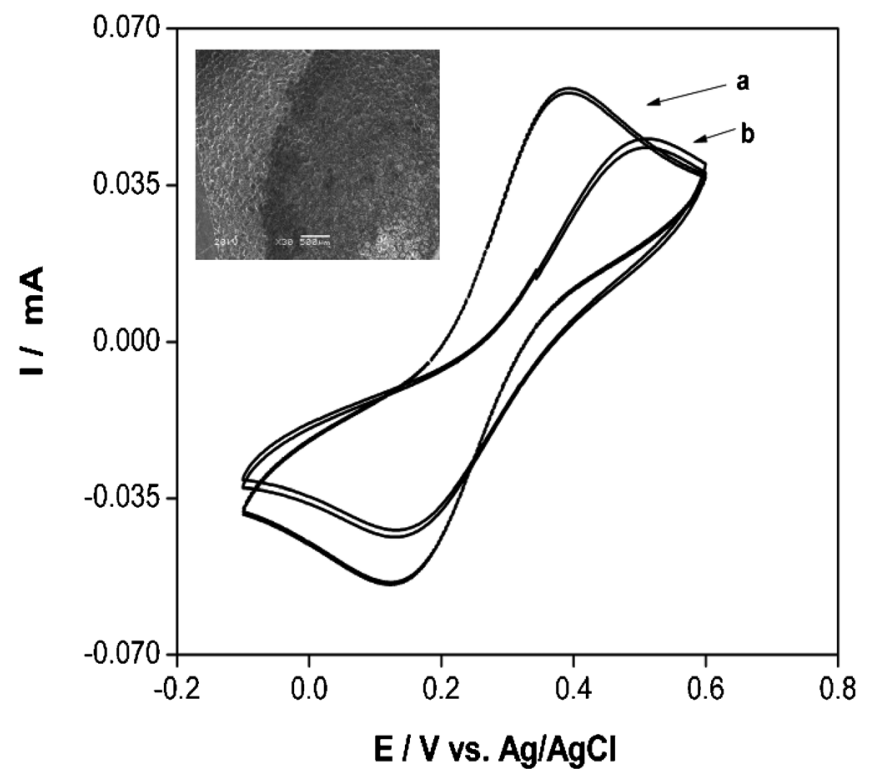

Fig. 1. Cyclic voltammograms of $1 \mathrm{mM} \mathrm{Fe}(\mathrm{CN})_{6}{ }^{3-/ 4-}$ in $0.10 \mathrm{M}$ $\mathrm{KCl}$ at a boron doped diamond (BDD) electrode before and after the oxidation process at a scan rate of $100 \mathrm{mV} / \mathrm{s}$. Inset: Scanning electron microscope image for the oxidized BDD electrode, at $20 \mathrm{kV}$ and $30 \times$ magnification.

tion 2.2. Figure 2 shows an SEM image of the platinized boron-doped diamond electrode (Pt-BDD), where the platinum nanoparticles are visible and it is also noticeable that the platinum nanoparticles showed preference for being electrodeposited on certain facets of the diamond. This preferential electrodeposition behavior has been the subject of investigation in recent years and it is mostly ascribed to the conductivity of the different facets of the BDD [18].

After each electrodeposition the Pt-BDD was accounted for the electrochemical active surface by calculating

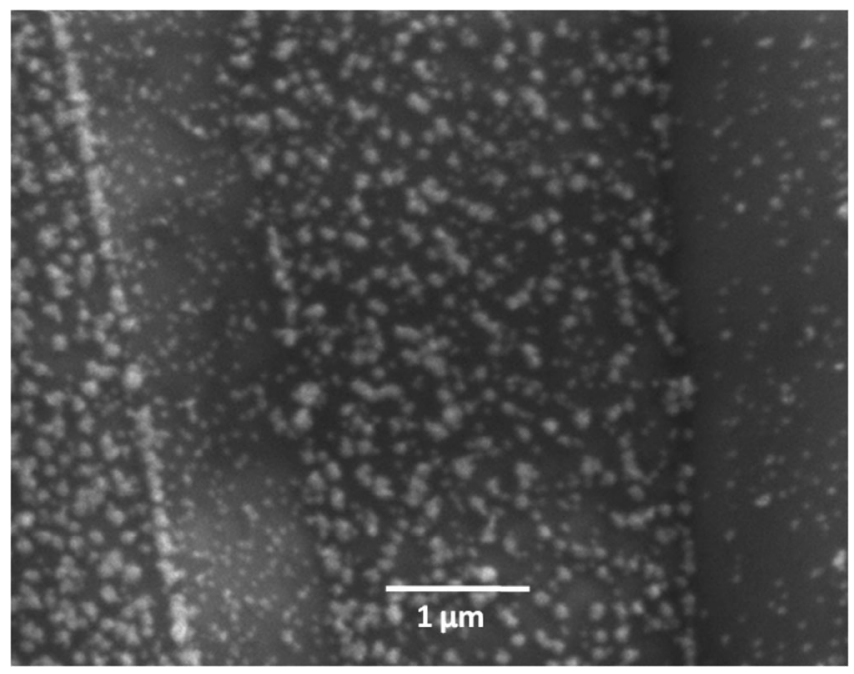

Fig. 2. Scanning electron microscopy image for the electrodeposited $\mathrm{Pt}$ nanoparticles at a boron doped diamond electrode, at $20 \mathrm{kV}$ and $20 \mathrm{k} \times$ magnification. 
the area under the hydrogen desorption peaks after running a $0.5 \mathrm{M} \mathrm{H}_{2} \mathrm{SO}_{4}$ cyclic voltammetry. Therefore, the results for the proposed sensor are normalized by the effective active area of platinum in the electrode, and shown as the current density, $j$. In general after each platinum electrochemical deposition an approximate area of $0.615 \mathrm{~cm}^{2}$ is attained.

\subsection{Ammonia Electrooxidation at Pt-BDD}

As explained in Section 1, the proposed sensor employs the enzyme urease to convert urea to ammonia, and the ammonia molecules are then electrooxidized at the interface of the Pt-BDD. Therefore, in an effort to understand the ammonia electrooxidation profile at different $\mathrm{pH}$ 's at the Pt-BDD two $0.1 \mathrm{M}$ ammonium sulfate solutions at pH 7.4 and 8.3 were tested. The $\mathrm{pH} 7.4$ was utilized because at this $\mathrm{pH}$ the enzyme has the highest activity according to the vendor, while $\mathrm{pH} 8.3$ was chosen because at this $\mathrm{pH}$ the enzyme is expected to still have considerable activity and the ammonia/ammonium ion equilibrium is more favorable for the ammonia oxidation since the chemical equilibrium is shifted to the formation of ammonia. Figure 3 shows the linear polarization of the two $0.1 \mathrm{M}\left(\mathrm{NH}_{4}\right)_{2} \mathrm{SO}_{4}$ solutions at $\mathrm{pH} 7.3$ and 8.3.

As can be observed the peak current density was higher for the solution with the higher $\mathrm{pH}$ level due to the expected higher concentration of ammonia due to shifting in chemical equilibrium. In addition, in this graph is noticeable that the oxidation potential for ammonia has shifted to lower values as the $\mathrm{pH}$ increase, though this is predicted by the Nernst equation. Thus, due to the fact that a higher signal-to-noise ratio can be obtained at $\mathrm{pH} 8.3$ the sensor experiments were executed at such $\mathrm{pH}$. As stated above, this $\mathrm{pH}$ value satisfies the necessity of

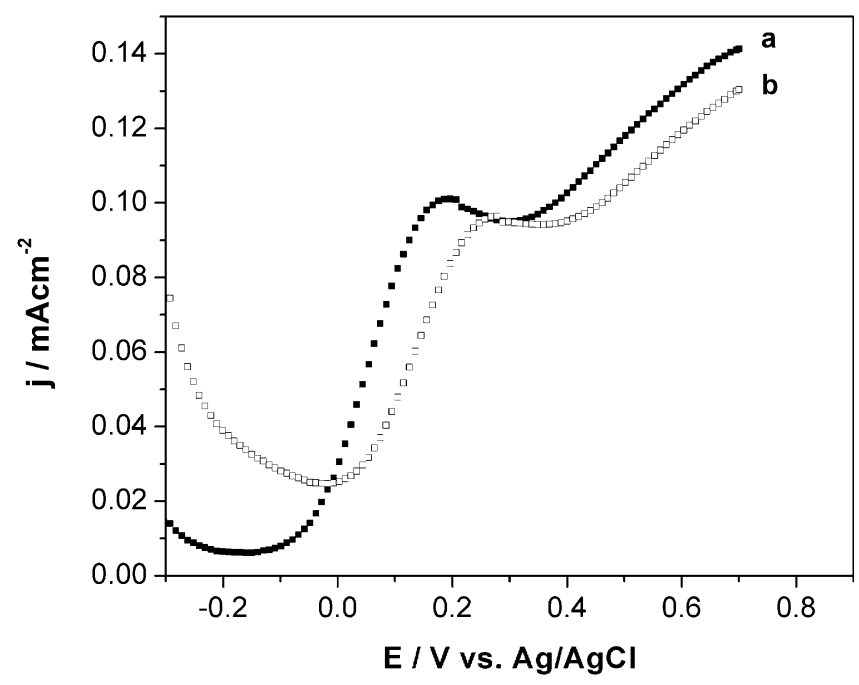

Fig. 3. Linear polarization of the ammonia oxidation at $\mathrm{Pt}$ nanoparticles at a boron doped diamond electrode in an ammonium sulfate solution in phosphate buffer solution at $\mathrm{pH} 7.4$ and 8.3. Scan rate of $100 \mathrm{mV} / \mathrm{s}$. a sensitive sensor without losing all enzyme activity, which is critical for a successful biosensing system.

\subsection{Urea Bioprobe Experiments}

The biomolecule activity and its ability to recognize an analyte is perhaps one of the most critical features of a biosensig device. Thus, the activity of the enzyme urease was determined via the Weatherburn Method. During the assay, the enzyme's activity was measured for two different urea concentrations, $5 \mathrm{mM}$ and $100 \mathrm{mM}$, and different $\mathrm{pH} 7.4$ and 8.3. As expected, it was found that the enzyme's activity with a urea concentration of $100 \mathrm{mM}$ $(13.0 \pm 0.3 \mu \mathrm{mol}$ ammonia/min $\mathrm{mg}$ protein at $\mathrm{pH} 8.3)$ was twice of the activity of that at $5 \mathrm{mM}(6.5 \pm 0.2 \mu \mathrm{mol}$ ammonia/min mg protein at same $\mathrm{pH}$ ), at any given $\mathrm{pH}$. Also, the higher activity was found for the assay performed at $\mathrm{pH} 7.4$ in comparison to $\mathrm{pH} 8.3$ at both concentrations. Once the biochemical and electrochemical parameters were optimized, the proposed device was tested as a single unit. Here, the urea degradation by urease and the in-situ electrooxidation ammonia was carried out and assessed. For these experiments, all solutions were prepared in phosphate buffer at $\mathrm{pH} 8.3$ and the final concentration of the enzyme in the electrochemical cell was approximately $1 \mathrm{mg} / \mathrm{mL}$ after correction by UV-Vis at $280 \mathrm{~nm}$.

Different urea solutions ranging from $1 \mathrm{mM}$ to $100 \mathrm{mM}$ were used in order to test the proposed sensor by means of the DPV technique. In Figure 4 the DPV for the phosphate buffer blank (a), a $100 \mathrm{mM}$ urea solution (b), a $1 \mathrm{mg} / \mathrm{mL}$ urease solution (c), and a $100 \mathrm{mM}$ urea-urease system (d) are presented. Before any voltage is applied to the electrochemical cell, the biochemical reaction between the substrate (i.e. urea) and the enzyme was allowed to equilibrate for five minutes for the enzyme to start degrading the urea, producing ammonia in order to have a measurable current.

As can be observed, a different current-potential profile is obtained when comparing the urea-urease system against the blanks. In the graph corresponding to the urea-urease system (Fig. 4d), a distinguishable peak was observed around $0.0 \mathrm{~V}$ vs. $\mathrm{Ag} / \mathrm{AgCl}$, which belongs to the ammonia oxidation. For the urea and enzyme blanks, this peak was more like a shoulder with negligible current. Also, in these two blanks as in the urea-urease experiments, a broad peak was observed between $0.2 \mathrm{~V}$ and $0.7 \mathrm{~V}$ vs. $\mathrm{Ag} / \mathrm{AgCl}$, therefore it may be related to the buffer, a common specie for all solutions. However, in the buffer blank a strong peak was observed, suggesting that the presences of other species are able to attenuate the buffer signal. After testing the proposed device, two important features of the sensor were determined, sensitivity and selectivity. First, the sensitivity indicates the minimum measurable urea concentration and the signal variation due to increasing urea concentration. To determine the sensitivity of the sensor the construction of a calibration curve was performed. The differential pulse voltammetry 

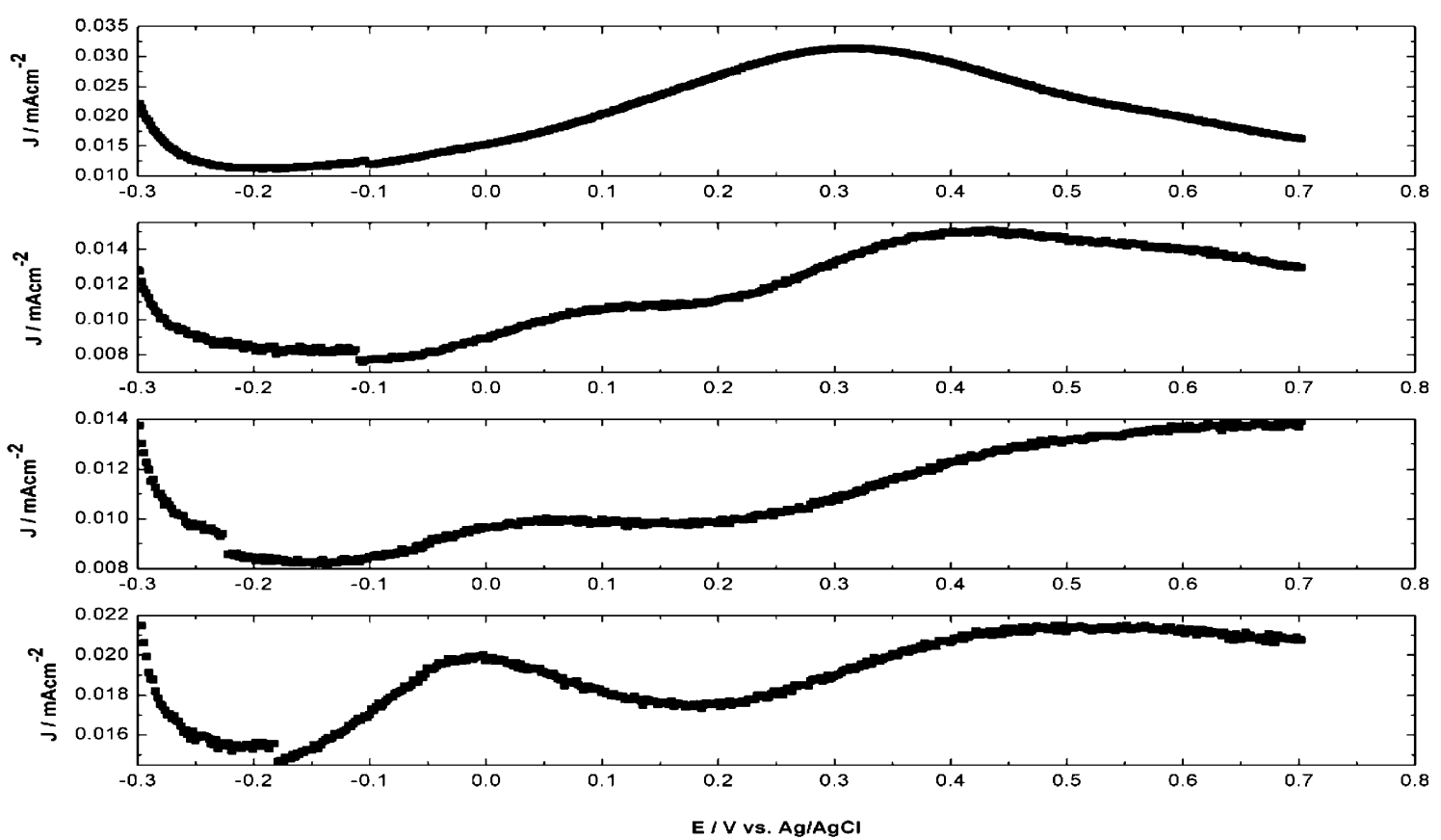

Fig. 4. Differential pulse voltammetry: (a) blank buffer, (b) $100 \mathrm{mM}$ urea solution, (c) $1 \mathrm{mg} / \mathrm{mL}$ urease solution and (d) $100 \mathrm{mM}$ urea-urease system at $\mathrm{pH} 8.3$. Pulse height of $50 \mathrm{mV}$, pulse duration of $50 \mathrm{~ms}$, step height of $2 \mathrm{mV}$, and step duration of $400 \mathrm{~ms}$.

(DPV) was used as a very sensitive method with sub-micromolar detection limit Thus, for such calibration curve urea solutions ranging from $1 \mathrm{mM}$ to $25 \mathrm{mM}$ were analyzed in the bioprobe device. The results showed an increment in the anodic wave due to increasing concentration of urea as can be observed in Figure 5a.

A linear dynamic range from $1 \mathrm{mM}$ to $25 \mathrm{mM}$ with a detection limit of $1.79 \mathrm{mM}(S / N=3)$ is obtained for urea detection with a slope of $0.343 \mu \mathrm{A} \mathrm{cm} / 2 / \mathrm{mM}$ and a correlation coefficient $\left(\mathrm{R}^{2}\right)$ of 0.9980 , see Figure $5 \mathrm{~b}$. The results of the analytical determination of urea by this method are sensitive enough to enable the construction of biosensors for clinical and analytical applications. In fact, the sensitivity of this system is similar to other urea bioprobes and biosensors reported in the literature [19-21]. Although more recent investigations have shown the enhanced urea determination to limits of detection of $10 \mu \mathrm{M}$ and linear range of $20 \mathrm{mM}$ due to the use of hybrid materials containing nanofiber[22].

\subsection{Selectivity Measurements (Interference)}

As abovementioned, two important features for any sensor are, sensitivity and selectivity. The sensitivity of the proposed sensor was determined previously with the calibration curves. Now, in order to determine the selectivity of the sensor, a compound similar in size and composition to urea is measured. From the different nitrogenous based compounds, creatinine was chosen to be studied as interference for the urea sensor, due to its similar size and structure to urea, but also for its presence in blood (i.e. $50-130 \mu \mathrm{M})[23,24]$. Another important argument to use creatinine as an interferent is that this compound is found in concentrations that are ten times higher for patients with kidney problems [25].

Creatinine, as urea, is not an electroactive specie as ammonia. Therefore when a solution of creatinine was measured in the biosensor no significant current was obtained, as with blank urea. Then, when a mixture of creatinine and urease was measured in the sensor, no current was obtained, meaning that the enzyme did not produce any ammonia because its selectivity towards urea. Finally, it was found that creatinine does not inhibit the enzyme's activity, since urease was able to degrade urea in the presence of creatinine, where a significant current was measured.

\section{Conclusions}

A bioelectrochemical device capable of measuring urea at levels of clinical importance was developed. The biosensor developed is capable of measuring urea levels as low as $1.79 \mathrm{mM}$ which is in the normal range (i.e. 2.5$7 \mathrm{mM}$ ) for a healthy individual. Moreover, the linear range presented by this sensor enables measurements of higher urea levels. Another analytical importance feature of the present method is that the presence of other similar molecules does not show considerable effects on the anodic peak current of ammonia. Therefore, the presented biosensor can be considered as a very sensitive and reasonably selective approach for urea determination.

Further investigations will assess the selectivity of the sensor in presence of complex matrixes such as blood. 

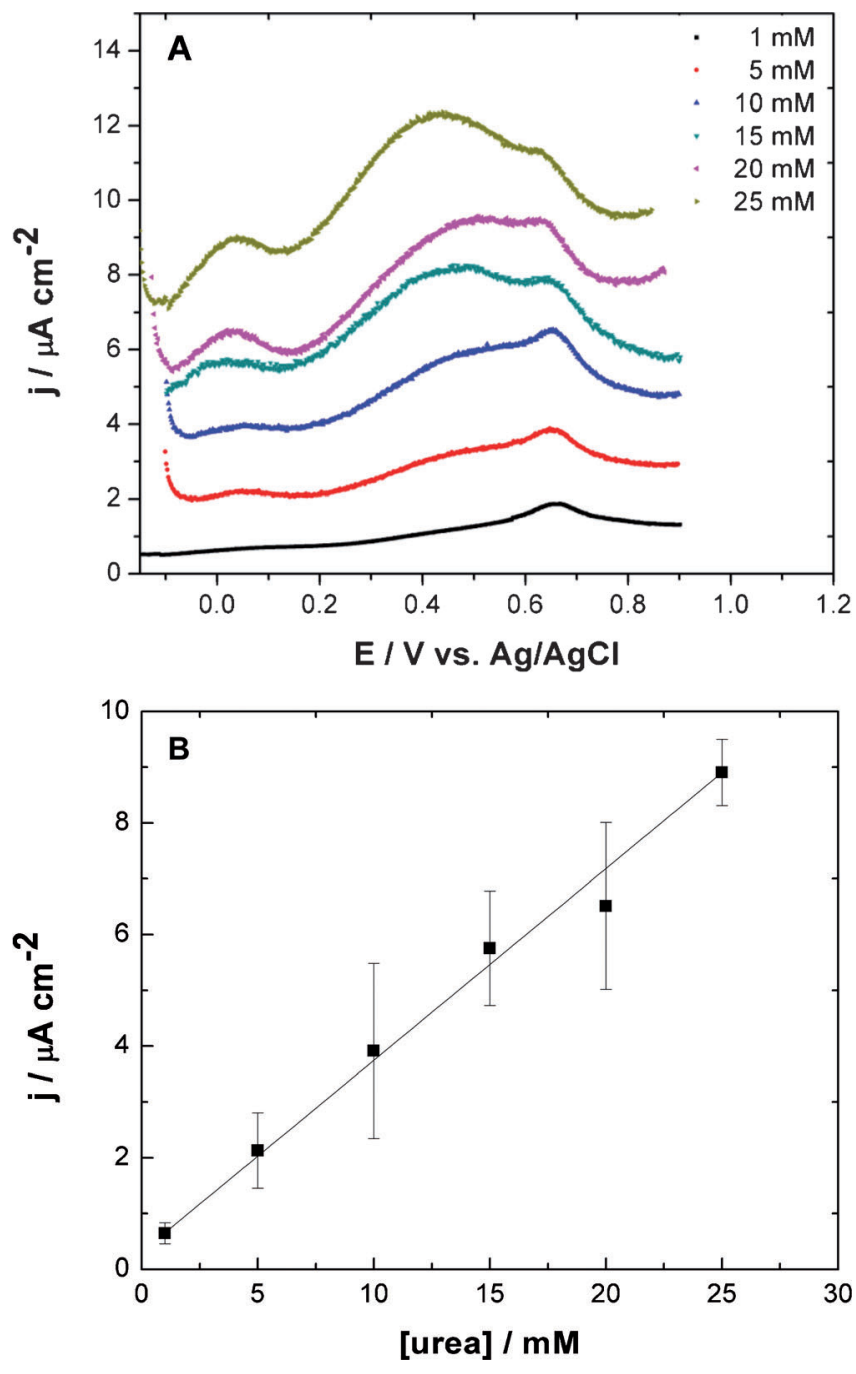

Fig. 5. (a). Differential pulse voltammetry of the ammonia oxidation for urea solutions of increasing concentration. Pulse height of $50 \mathrm{mV}$, pulse duration of $50 \mathrm{~ms}$, step height of $2 \mathrm{mV}$, and step duration of $400 \mathrm{~ms}$. (b). Calibration curve for the biosensor, with linear range from $1 \mathrm{mM}$ to $25 \mathrm{mM}$ and detection limit of $1.79 \mathrm{mM}(S / N=3)$, slope $=0.343 \mu \mathrm{A} \mathrm{cm} / \mathrm{mM}$. The data was obtained from (a).

\section{Acknowledgements}

This work was financially supported by NASA-URC Center for Advanced Nanoscale Materials at the University of Puerto Rico Río Piedras Campus under Grant No. NNX08BA48A and NNX10AQ17A and by the NSF Center for Hierarchical Manufacturing at the University of Massachusetts under Grant No. CMMI-0531171. E. Nicolau greatly appreciates NASA Graduate Student Researchers Program (GSRP), under Grant No. NNX08AV42H, and NASA Jenkins Pre-doctoral Fellowship Program for the financial support. J. Fonseca acknowledges the MARC Program and RISE Program at the University of Puerto Rico-Río Piedras Campus for continuous financial support.

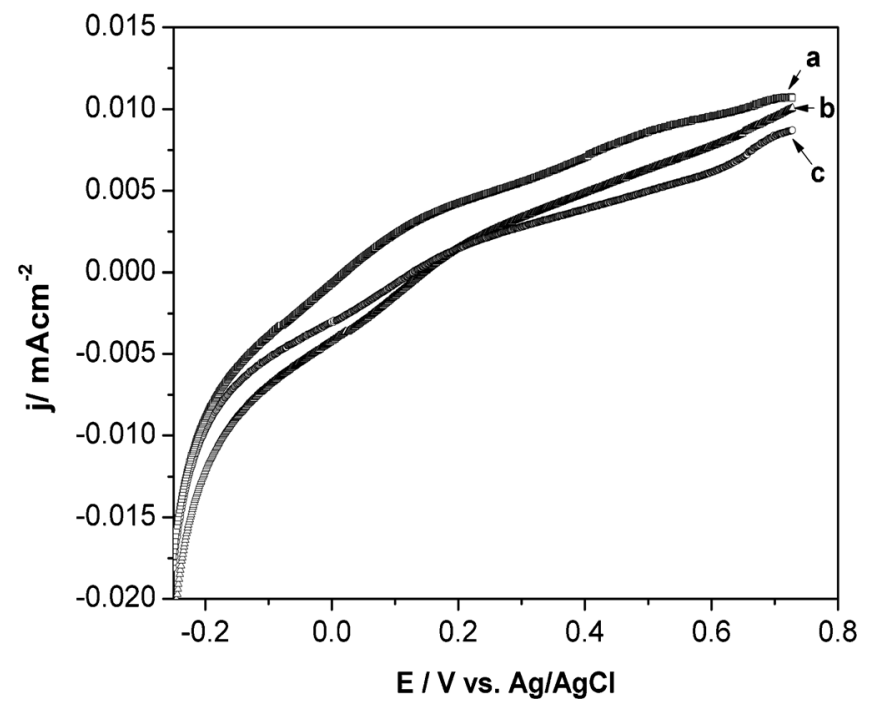

Fig. 6. Creatinine linear polarization: (a) $50 \mathrm{mM}$ of creatinine, $10 \mathrm{mM}$ of urea, and $0.5 \mathrm{mg} / \mathrm{mL}$ of urease in $100 \mathrm{mM}$ PBS solution, (b) $50 \mathrm{mM}$ of creatinine $100 \mathrm{mM}$ PBS solution, (c) $50 \mathrm{mM}$ of creatinine and $0.5 \mathrm{mg} / \mathrm{mL}$ of urease in $100 \mathrm{mM}$ PBS solution. Scan rate of $5 \mathrm{mV} / \mathrm{s}$.

\section{References}

[1] R. Koncki, Anal. Chim. Acta 2007, 599, 7.

[2] B. Premanode, C. Toumazou, Sens. Actuators B 2007, 120, 732.

[3] D. C. Dugdale, J. M. Vyas, MedlinePlus Medical Encyclopedia, BUN 2008.

[4] Kidney and Urologic Diseases Statistics for the United States, NIH, Washington, DC 2008.

[5] C. Follmer, Phytochemistry 2008, 69, 18.

[6] R. H. Leonard, Clin. Chem. 1963, 9, 417.

[7] P. Niedzielski, I. Kurzyca, J. Siepak, Anal. Chim. Acta 2006, $577,220$.

[8] A. Afkhami, R. Norooz-Asl, J. Braz. Chem. Soc. 2008, 19, 1546.

[9] J. Georges, Clin. Chem. 1979, 25, 1888.

[10] S. K. Jha, A. Topkar, S. F. D'Souza, J. Biochem. Biophys. Methods 2008, 70, 1145.

[11] J. C. Chen, J. C. Chou, T. P. Sun, S. K. Hsiung, Sens. Actuators B, Chem. 2003, 91, 180.

[12] B. V. Rajesh, W. Takashima, K. Kaneto, Biomaterials 2005, $26,3683$.

[13] R. Sahney, B. K. Puri, S. Anand, Anal. Chim. Acta 2005, $542,157$.

[14] A. Maaref, et al., Sens. Actuators B, Chem 2007, 123, 671.

[15] M. Hupert, A. Muck, R. Wang, J. Stotter, Z. Cvackova, S. Haymond, Y. Show, G. M. Swain, Diamond Relat. Mater. 2003, 12, 1940.

[16] M. W. Weatherburn, Anal. Chem. 1967, 39, 971.

[17] M. F. Ghasemi, M. R. Bakhtiari, M. Fallahpou, A. Noohi, N. Moazami, Z. Amidi, IROST 2003, 2008.

[18] C. R. Cabrera, I. Gonzalez-Gonzalez, D. A. Tryk, Diamond Relat. Mater. 2006, 15, 275.

[19] Z. Xu, X. Chen, X. Qu, J. Jia, S. Dong, Biosens. Bioelectron. 2004, 20, 579.

[20] P. Thavarungkul, H. Hakanson, O. Holst, B. Mattiason, Biosens. Bioelectron. 1991, 6, 101.

[21] P. Bertocchi, D. Compagnone, G. Palleschi, Biosens. Bioelectron. 1996, 11, 1. 
[22] J. Wenzhao, L. Su, L. Yu, Biosens. Bioelectronics 2011, 30 , 158.

[23] C. F. Seifert, B. H. Resman-Targoff, in Textbook of Therapeutics: Drug and Disease Management, 8th ed. (Eds: R. A Helms, D. J. Quan), Lippincott Williams \& Wilkins, Philadelphia, PA 2006, p. 93.
[24] A. Skurup, T. Kristensen, G. Wennecke, Clin. Chem. Lab. Med. 2007, 46, 3.

[25] S. Nabili, MedicineNet - Creatinine Blood Test, (Ed: W. C. Shiel), 2008. 